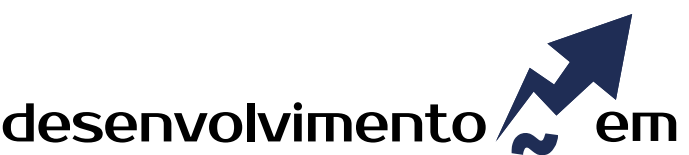 QUESTÂO
}

\section{Recife, City of People? \\ A study based on the archeology of Foucault}

http://dx.doi.org/10.21527/2237-6453.2020.50.24-40

Recebido em: $17 / 2 / 2018$

Aceito em: 6/9/2019

Duarte Raab Pires ${ }^{1}$, Maria Luciana de Almeida², Lilian Soares Outtes Wanderley³

\begin{abstract}
This article aims at analyzing the discourse involved in the city council program called "Recife, city of the people", from Foucault's archeology of knowledge perspective. The corpus of this research consists of six videos available on the Facebook ${ }^{\circledR}$ page of the city council of Recife in 2014, when government agency released the slogan "Recife, Cidade das Pessoas". The study is justified by the need of understanding how the political discourses are spread and how these discourses have no explicit assumptions. We believe that a better design of the influence of discourses, along with further clarification of social significance exercised by them, can contribute to a more democratic social life, which will be accessible to the entire population. For the present study, no theory was previously defined. The option for this construction enables the non-interference of external factors guiding the analyses. Data was analyzed without theoretical influences, so that the theoretical constructs emerged from the analysis rather than the reverse. However, the vision of authorship in relation to the concept of speech interferes with the analysis and serves as a theoretical lens through which data will be displayed. For results, two discursive formations were found: (1) the protection of the Government and (2) healthy lifestyles practices, with includes social, cultural and physical. This discursive formation is founded on the pillars of bio-politics and sustainability, quality of life and social change. It was noticed that the program has a goal it is to influence people's opinions about public spaces and mobility in a municipality.
\end{abstract}

Keywords: Discourse. "Recife, City of People". Archeology of knowledge. Public spaces.

RECIFE, CIDADE DAS PESSOAS? UM ESTUDO BASEADO NA ARQUEOLOGIA DE FOUCAULT

RESUMO

Este artigo tem por objetivo analisar o discurso envolvido em um programa intitulado "Recife, Cidade das Pessoas", sob a perspectiva da arqueologia do saber de Foucault. O corpus da pesquisa foi constituído por seis vídeos disponíveis no Facebook $^{\circledR}$, na página da prefeitura do Recife. O estudo é justificado pela necessidade de entender como os discursos políticos estão espalhados e como esses discursos não possuem premissas explícitas. Acreditamos que um melhor desenho da influência dos discursos, juntamente com mais esclarecimentos sobre o significado social exercido por eles, pode contribuir para uma vida social mais democrática, que será acessível a toda a população. Não houve uma definição apriorística de teorias para o presente estudo, de forma a reduzir a interferência de fatores externos na estruturação da análise. Os dados foram analisados sem influências teóricas, de modo que as construções teóricas emergiram da análise e não do contrário. No entanto, a visão da autoria, em relação ao conceito do discurso, interfere na análise e serve como uma lente teórica por meio da qual os dados foram exibidos. Como resultados, duas formações discursivas foram encontradas: (1) a proteção do Governo e (2) práticas de estilos de vida saudáveis, que inclui o aspecto social, cultural e físico. Estas formações discursivas alicerçam-se nos pilares da biopolítica e da sustentabilidade, qualidade de vida e mudança social. Observou-se que o programa tem como objetivo influenciar as opiniões das pessoas sobre espaços públicos e mobilidade naquele município.

Palavras-chave: Discurso. "Recife, Cidade de Pessoas”. Arqueologia do saber. Espaços públicos.

\footnotetext{
${ }^{1}$ Mestre e doutorando em Administração pela Universidade Federal de Pernambuco (Ufpe). Agente da Polícia Rodoviária Federal (PRF). prfduarteraab@gmail.com

${ }^{2}$ Doutora em Administração pela Universidade Federal de Pernambuco (Ufpe). Professora da Universidade de Pernambuco (UPE). lucianalmeida.pe@gmail.com

${ }^{3}$ Doutora em Administração pela Universidade de Cambridge, Grâ-Bretanha. Professora da Universidade Federal de Pernambuco (Ufpe). lilian.wanderley@ufpe.br
} 
Nowadays, the organizational image value is an undeniable factor for its success. In an era in which information is quickly disseminated and people construct their meanings based on the understanding that each individual has about how institutions behave, to build a solid reputation becomes a challenge. In this scenario, public or private organizations seek to highlight their actions and attitudes in order to consolidate a positive image across society.

In the political system it is no different, rulers seek praise for their achievements, thereby building an image that is positively valued by the citizens they represent. Understanding that our reality is socially constructed (BERGER; LUCKMAN, 1967) and that the actions performed daily are constituted as social practices (SHOVE, 2012) which are permeated by discourses (FAIRCLOUGH, 2001), the establishment of individual perceptions is widely influenced by widespread social discourse. Thus, the institutions seek to disseminate discourses that lead people to perceive themselves in a certain way, aiming to obtain identification from the public.

In 2014, the city of Recife, located in the Northeastern Brazil, capital of Pernambuco state, announced the slogan City of People - Cidade das Pessoas, which invites the local population to enjoy the experience of living in the city. Throughout the year this call got spread via videos posted on the Facebook page of the City Hall, newspapers and news events held in public places; all these events highlighting the enjoyable usage of public spaces. Messages on the televised news were disclosed in this direction, with highlights to the bicycle lanes, involving the adoption of the bike and related to the urban mobility project of the state government; the occupation of the Old Recife on a regular basis and other neighborhoods of spaced and interleaved mode, which is part of two municipal projects: the Old Recife of the Heart - Recife Antigo de Coração - and Recife of the Heart - Recife de Coração no Bairros - in the the central region and in the suburbs, respectively. In parallel, there is the implementation of Ecopontos and the call of the population to use these spaces. This directive was created by the environmental department of the City Hall project called Educating for a Sustainable City - Educar para uma cidade Sustentável, which seeks to work together with all departments.

In this context, we wonder what assumptions shape the discourse "Recife city of the people". Given this concern, this article aims at analyzing the speech Recife city of the people from Foucault's archeology of knowledge perspective. Six institutional videos were selected, all published by the city of Recife in 2014, which aimed to spread the message "City of the people", which are subjected to Foucauldian discourse analysis.

This study is justified by the need of understanding about how the political discourses are spread and how these discourses have no explicit assumptions. We believe that a better design of the influence of discourses, along with further clarification of social significance exercised by them, can contribute to a more democratic social life, which will be accessible to the entire population.

\section{THEORETICAL LENS: Discourse, an Essential Social Practices Factor}

Given the nature of the study, not theory was previously defined. The option for this construction enables the non-interference of external factors guiding the analyses. Therefore, the data was analyzed without theoretical influences, so that the theoretical 
constructs emerged from the analysis rather than the reverse. However, the vision of authorship in relation to the concept of speech interferes with the analysis and serves as a theoretical lens through which data will be displayed. Being aware of this fact, the main considerations about the concept of social life and discourse which was adopted in this work is presented in the next paragraph.

Starting from the social life understanding of "interconnected networks of social practices of different types [...]" and realizing that "every social practice is an articulation of diverse social elements in a relatively stable configuration, always including discourse" (FAIRCLOUGH, 2001, p. 231), for which practices are permeated by discourses and these are fundamental to understanding the society. In seeking to understand how meanings are given to the world we live in, Spink and Frezza $(2013$, p. 15) corroborate with the concept of reality as a social construction (BERGER; LUCKMAN, 1967) understanding that "in our everyday lives, we are, Indeed, products of our time and we cannot escape the conventions, the moral legitimacy of orders and structures". These conventions are socially constructed and historically located (BERGER; LUCKMAN, 1967; SPINK; FREZZA, 2013). Thus, to promote social change is to understand the reality constructions legitimized in the social context imagining them otherwise and conceiving the possibility of changes.

In this sense, the discourse is fundamental for the maintenance, modification and redefinition of the social order. The address corresponds to "different ways of acting" as constituting "distinct representations of social life derived from the positions taken" (FAIRCLOUGH, 2001, p. 232). The daily practices are guided by the rules, regulations and conventions located in a given social context, such practices tend to maintain and reproduce discourses (SPINK; MEDRADO, 2013). The reality of meanings are designed by actors, who visualize the world from the positions they occupy in society, therefore, it is guided by the bases accepted in their context and attribute different meanings to the facts, representing them through multiple discourses. Thus, the discourses "include representations of how things are and have been, as well as imaginary, perceived as representations of how things would be, should or could be" (FAIRCLOUGH, 2001, p. 234).

The knowledge of reality is not something inherent to the individual, but a collective construction from social context experienced in certain time, so changes in conceptions of reality depend on the defamiliarization of culturally rooted beliefs. The conventions socially constructed impose various cultural obstacles to the emergence of new constructions, in terms of beliefs and values, defamiliarization process creates the possibility of new constructions, even if they are impregnated by existing cultural conventions (SPINK; MEDRADO, 2013). Thus, "the process of 'changing the subject' can be thought of in terms of inculcating new discourses" (FAIRCLOUGH, 2001, p. 234). Even strong discourses meet some resistance to be inculcated, but this process is necessary to transform understandings of life in society. Taylorism, for example, was a widespread production and management system, but its existence was only possible from a few changes in the way of being and beliefs of workers of the time (GRAMSCI, 1971).

As Chappells, Medd and Shove (2011, p. 712) there are concrete evidences that the discourse can generate changes in patterns socially acceptable, and it may even enhance, create or recreate the social norms. Thus, it is important to understand which habits and routines are disseminated and incorporated into the day-to-day lives. This 
requires understanding of how new socio-technical arrangements, these arrangements emerging from the interaction between agency and structure, arise and how to stimulate these arrangements lead to new forms of social action. However, new arrangements at the same time, break with old structures, incorporate these elements, which entails the need to understand the historical context of socio-technical arrangements (SHOVE, 2012).

For change of discourse to become effective in the transformation of practices it is necessary that the materials and structures associated with them are available to people. The practical knowledge on performing everyday activities is guided by structural aspects, such as rules and resources. To perform their tasks, individuals need to have at their disposal the resources associated with them. You cannot play football without a field, a ball and some form of catch, and it is not possible that people intended to correct the waste bin for each type of material if there are different trash baskets (SHOVE; PANTZAR; WATSON, 2012). Decision makers have the power to influence the process of distributing materials and resources.

\section{METHODOLOGICAL PROCEDURES}

Against the background of our world view, constructivism as a paradigm is adopted. Turning to study questions related to the understanding of human life in its specificities, constructivism makes room for interpretation of the investigator about the phenomena. Investigations founded by the constructivist paradigm have a naturalistic and interpretative focus of reality (DENZIN; LINCOLN, 2006; PAIVA MELLO, 2008). Constructivists argue that individuals construct meaning about the reality in which they live. From this perspective, people develop subjective understandings about their experiences, and these are multiple and varied understandings. The research aim is to explore the meaning of the multiple meanings people attribute to the world (CRESWELL, 2010).

Thus, this study followed an interpretative line. The interpretive research assumes that reality is not just noticeable, but socially constructed. Thus, the same phenomenon can be understood in several ways. From this perspective, knowledge does not come from the researcher, but is constructed by the researcher from observation and interaction in the context studied (MERRIAM, 2009). We adopted, thus a subjective vision, whereby the findings were built from the interpretation of the study reality (LINCOLN; GUBA, 2006). In this sense, we have guided by an inductive approach, based on the qualitative method. Qualitative research is an "umbrella concept covering various forms of research that help us understand and explain the meaning of a social phenomenon with the least possible disturbance of the natural environment" (MERRIAM, 1998, p. 12).

The corpus of this research consists of six videos available on the Facebook ${ }^{\circledR}$ page of the city council of Recife since 2014, which deal with the subject under study. This was the year in which the said government agency released the slogan "Cidade das Pessoas" ("City of the people") which was broadcasted by disseminating videos with calls for public events or information on the actions taken. In order to compose the corpus was carried out a search in a virtual environment on the publications from the Local Government, it means a Facebook ${ }^{\circledR}$ page, which gathers all types of virtual media, such as television or news and more other information. Since then, the posts of 2014 have been analyzed and it reached a total of six videos that relate directly to the studied theme. 
Each video is $1 \mathrm{~min}$ long, 1:01 $\mathrm{min}$ to be precise. In order to illustrate the video content some images were chosen and added to the enouncements presented in section 4, discussion of results.

It is noteworthy also to emphasize that this corpus was focused in a production of content, journalistic, informative character of a fact, however, has at its heart the intrinsic intention of promotion. It is produced by the municipal government interest, a press office or PR and aims to enlist news space for promotion by a professional communication, that is, by an attempt to establish with the pubic reader a positive image about their strategies organizational (MCLUHAN, 2001).For the application of archaeological analysis of the videos, not sought to interpret them directly, however, work them and order them, making their enunciation units, their relationships and interrelationships, functions, thus structuring the entire archaeological process (FOUCAULT, 2007). Early in the process we were not linked with a particular theory that can lead us to any direct the findings, or the construction of knowledge. Based on the above and on the fact that the enouncements precede the meanings in the midst of a process of abstraction, sought the formation or construction of statements through the analysis, since this is neither in the texts nor the signs the latter background of meanings. This analysis, however, was based on the materiality of social practice in this corpus, and not a possible abstraction. The corpus, in turn, reflects the social practice, which for Foucault (2007) is a discursive practice, and as such comes from a social practice, historically limited, concrete, and therefore builds the knowledge.

Enouncements correspond to a smaller unit of analysis of the discourse, or the minimum unit of truth for Foucault (2007), or through the enouncement it is possible to access the smaller unit of knowledge. Through the enunciative functions and their interrelations, the statements begin to have a sense of being and vice versa functions in relation to the statements.

The application of the above, this study occurred through the separation and re-ordering of discursive texts and pictures with common qualitative characteristics, ie to appoint the same discursive text for the same space, time and context. These sets were categorized into enouncements and by analyzing their relations with the context functions were established, even without any pre-existing theoretical framework. The intention was not to prove theories, however, check them if chance to emerge from the analyzes carried out, after the enunciative function is not limited to textual content, it stems from the intention in practice or pragmatic discourse, it is therefore plausible and feasible get to the functions without resorting to theories, which were incorporated later.

Such short videos were distributed via social media in general and it is difficult to estimate number of times there were on television channels and how many people have watched each. Recife's population is about 4 million and the slogan "City of People" also became available on outdoors.

Thus, we can say that from the corpus were structured three analytical components, namely the (1) stated that contextually have (2) functions, which are grounded in (3) operating rules, which are present around the discursive field. In the formation of the rules that were naturally research results emerged the need to resort to theories, since these relate to and use biopolitic disciplinary power with the aim of guaranteeing the second rule with respect to sustainability, quality of life and give rise to social change. Finally, they emerged two discursive formations resulting from the triangulation process of the elements presented above and the above rules. 


\section{APPLICATION OF ARCHAEOLOGY OF KNOWLEDGE Description of Results}

In this section, the results achieved in this study will be shown through the presentation, description and illustration of the enouncements, functions and rules that leads to the discourse construction. The relationship between the categories presented converges to some conclusions that allow unveiling the research objectives. At the end, we present the discursive formations that are inferred speech. The enouncements will be named, described (Figure 1) and exemplified below, in order to expand the understanding of themselves within their discursive practices, as well as to reveal their features.

Foucauldian archaeological analysis focuses on the main conceptual pairs of the human sciences: function and norm, conflict and rule, and meaning and system as primordial constituents of psychology, sociology, and study of literature and myth respectively (MACHADO, 1981; GOMES, 2018). According to Foucault, these pairs are related to empirical objects on the one hand, and to a transcendental philosophy on the other, and it is through the interaction of the two concepts, at the same time, in the respective human sciences, that endows them with singularity as such (MACHADO, 1981; GOMES, 2018). The definition of this interaction is the main objective of Foucault's archaeological analysis. For the application of the archaeological analysis of the documents, it was not sought to interpret the documents, or the other graphic symbols themselves, however, to work them and order them, composing their enunciative units, their relations and interrelationships, functions, thus structuring the entire archaeological process (FOUCAULT, 2007). At the beginning of the process, no attempt was made aprioristically to any specific theory that would support or direct the findings, or the construction of knowledge.

Based on the above and on the fact that the statements precede the meanings, in the middle of a process of abstraction, we sought the formation or construction of the statements through the analysis, since they are neither in the texts nor in the signs. last antecedents of meanings. This analysis, however, was based on the materiality of the social practice present in the corpus, and not on a possible abstraction (MACHADO, 1981; GOMES, 2018). The corpus, in turn, reflects social practice, which for Foucault (2007) is a discursive practice, and as such comes from a historically limited, concrete social practice, and therefore builds knowledge. The statements correspond to the smallest unit of discourse analysis, or the minimum unit of truth for Foucault (2007), or even through the utterance it is possible to access the minimum unit of knowledge. Through the enunciative functions and their respective interrelationships, utterances begin to have a sense of existence and vice versa of utterances in relation to functions (MACHADO, 1981; GOMES, 2018).

The application of the above in this study occurred through the separation and reordering of texts and images, with common qualitative characteristics, that is, constituting the same discursive text, for the same space, time and context. These sets were categorized into statements and through the analysis of their relations with the context, the functions were established, without any pre-existing theoretical support. The intention was not to prove theories, however, to verify them, if it emerged from the analyzes performed, after all the enunciative function is not restricted to textual content, it stems from the intention in discursive practice or pragmatics, and therefore plausible. 
It is feasible to arrive at functions without resorting to theories, which will be incorporated later (MACHADO, 1981; GOMES, 2018). Thus, it is possible to state that from the corpus four analytical components were structured, namely: (1) statements, which contextually have (2) functions, which are based on (3) operating rules, which are present throughout the discursive field and (4) the discursive formations, which consolidate or correspond to the discursive convergence of all foucauldian archaeological analysis. In figure 01 it is possible to see the beginning of the description of the archaeological analysis process, which will be presented throughout the research.

Figure 1 - Enouncements and descriptions

\begin{tabular}{|c|c|}
\hline Enouncements & Descriptions \\
\hline $\begin{array}{l}\text { 1. The Municipal Government invests } \\
\text { in quality of life, through structur- } \\
\text { al projects in the city guided by ex- } \\
\text { perts. }\end{array}$ & $\begin{array}{l}\text { The City Government aims to ensure a good } \\
\text { quality of life through structural projects in } \\
\text { the city, which are structured by renowned } \\
\text { and known experts }\end{array}$ \\
\hline $\begin{array}{l}\text { 2. The Municipal Government seeks } \\
\text { to promote entertainment in public } \\
\text { spaces mainly though fosports ac- } \\
\text { tivities, social coexistence and dis- } \\
\text { semination of local culture, at the } \\
\text { weekends. }\end{array}$ & $\begin{array}{l}\text { The local government aims to develop healthy } \\
\text { living habits for the population through their } \\
\text { programs that encourage social interaction, } \\
\text { through sporting activities and interaction } \\
\text { with the local culture on weekends, both on } \\
\text { the banks of river Capibaribe, as the center of } \\
\text { the city. }\end{array}$ \\
\hline $\begin{array}{l}\text { 3. Bike Lanes are set up at the week- } \\
\text { ends aiming alternative to urban } \\
\text { mobility and improving the health } \\
\text { of the population. }\end{array}$ & $\begin{array}{l}\text { The bike habit of walking in the bike lanes set } \\
\text { up by the city on weekends, with circuits that } \\
\text { emphasize the natural and historical beauties } \\
\text { of the city, both promote an alternative for } \\
\text { urban mobility with a better relationship with } \\
\text { the environment, and promotes habits for a } \\
\text { lifetime healthier. }\end{array}$ \\
\hline $\begin{array}{l}\text { 4. The Municipal Government foster } \\
\text { change habits in the population for } \\
\text { a better quality of life. }\end{array}$ & $\begin{array}{l}\text { One of the local government's objectives is to } \\
\text { create healthy habits through the use of pub- } \\
\text { lic space, the social life and enjoying both the } \\
\text { historical space and the natural beauty of the } \\
\text { city. }\end{array}$ \\
\hline $\begin{array}{l}\text { 5. The municipal government seeks to } \\
\text { create a city dedicated to its people. }\end{array}$ & $\begin{array}{l}\text { The local government aims to structure the } \\
\text { city for its residents to enjoy its historic and } \\
\text { natural wealth, feeling part of the city. }\end{array}$ \\
\hline $\begin{array}{l}\text { 6. The city government invests and en- } \\
\text { joys the natural resources of the city } \\
\text { particularly the banks of the river } \\
\text { Capibaribe, in order also to enhance } \\
\text { the quality of life of residents, as } \\
\text { well as provide new leisure and en- } \\
\text { tertainment options. }\end{array}$ & $\begin{array}{l}\text { Beyond the creation of healthy habits, great- } \\
\text { er interaction of residents to the city, the lo- } \\
\text { cal government provides new entertainment } \\
\text { options more focused on a direct relationship } \\
\text { with the direct enjoyment of the city. }\end{array}$ \\
\hline
\end{tabular}


Enouncement 1 - The Municipal Government invests in quality of life, through structural projects in the city guided by experts.

Three of the main projects of the Recife city hall began in 2014 were the Bike Lines Plan and the Urban Plan for the Rio Capibaribe Park - Path of Capybara, and the Heart of Recife Antigo - Polo Cultural, Artistic and Leisure. Analyzing the 03 projects, we can say that the bigger and more impacts in the city, both in financial terms and in deployment time, because of the geographical extent is the Urban Plan for the Rio Capibaribe Park. For the latter project has involved the Federal University of Pernambuco - UFPE, through specialists and renowned professors who participated not only the project itself, but also the dissemination and people of conviction, about the importance of it to improve the quality of life being promoted in the city.

Figure 2 - Experts discuss Project Parque Capibaribe

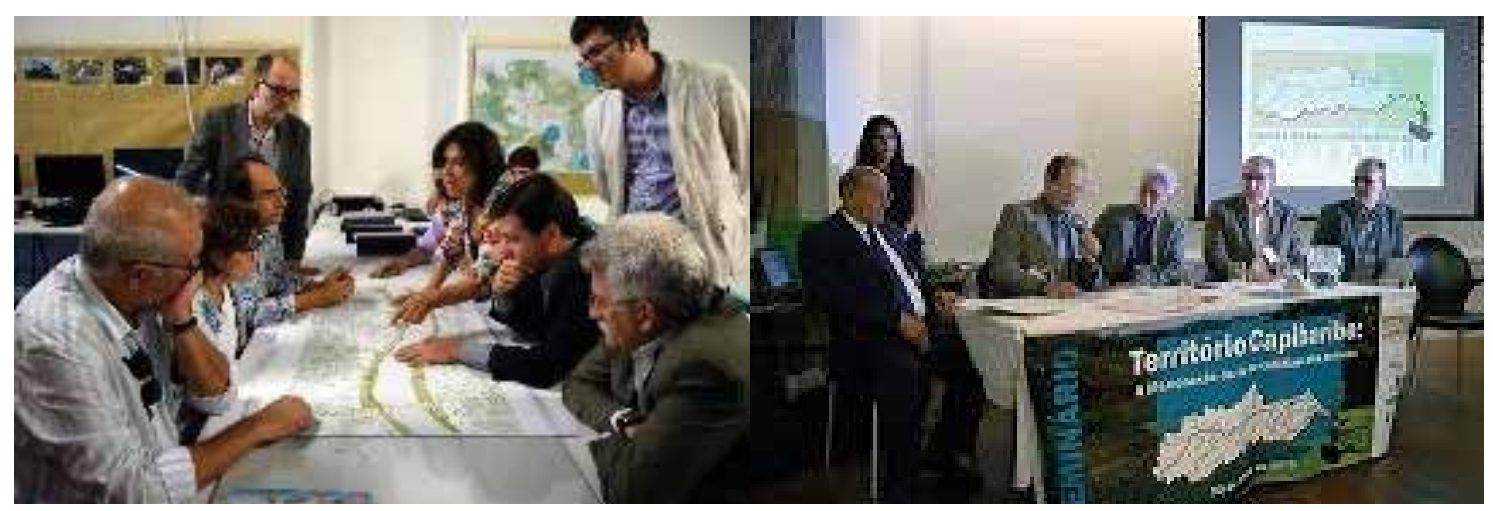

Source: COMUNIDADE PARQUE CAPIBARIBE, 2015.

Enouncement 2 - The Municipal Government seeks to promote entertainment in public spaces mainly though sports activities, social coexistence and dissemination of local culture, at the weekends.

It recurred and standardized the presence of images that contributed to the disclosure of this statement. In fact, this has been a constant in almost all utterance corpus films. It is clear the concern of discursive agent in promoting participation and the involvement of the population in activities offered and available in the city center - Old Recife and the banks of the Rio Capibaribe, on weekends.

Figure 3 - Integration and Community participation in the ancient City Center

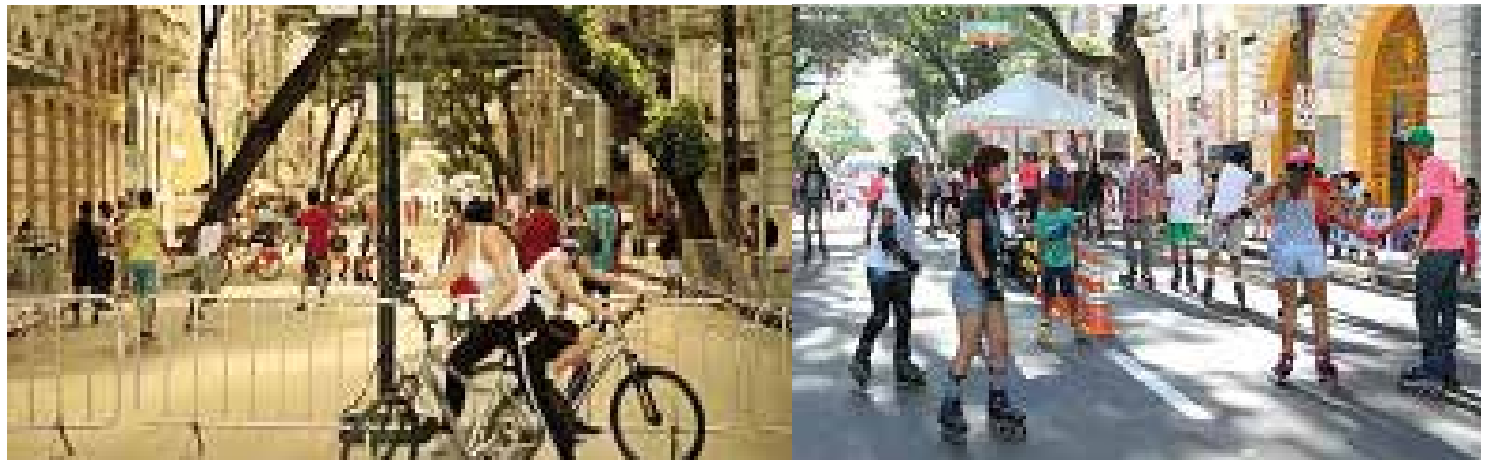

Source: PREFEITURA DO RECIFE, 2014. 
Enouncement 3 - Bike Lanes are set up at the weekends aiming alternative to urban mobility and improving the health of the population.

This statement has two main biases, namely: (1) an attempt to promote urban mobility in the non-working days and (2) an initiative to promote the habit of change if the insertion and motivation for a healthier lifestyle. What actually happens is encouraging the use of bicycles for entertainment on weekends, thus creating the possibility of knowledge of historic and natural beauty of the city, a healthy mobility option that generates no pollution, no traffic jams, and expansion of social coexistence.

Figure 4 - The use of bike lanes

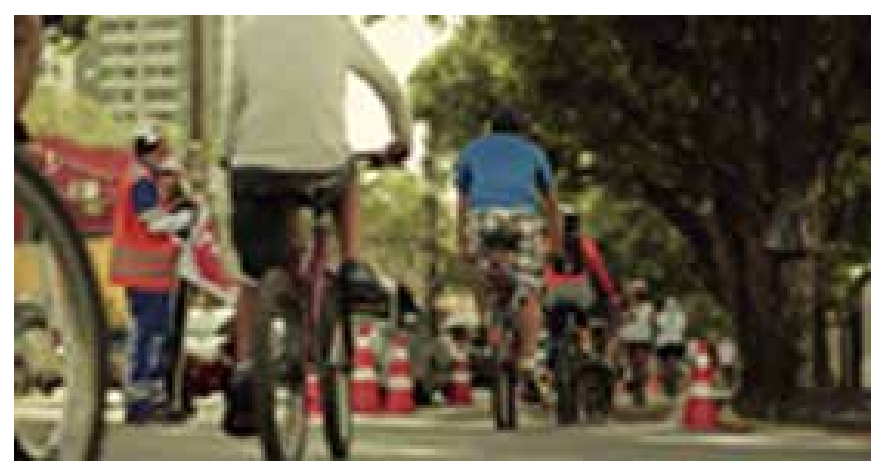

Source: PREFEITURA DO RECIFE, 2014.

Enouncement 4 - The Municipal Government foster change habits in the population for a better quality of life.

This statement refers to the efforts by the local government for the people of habits change, whether in relation to new forms of leisure, involving more healthy practices - skating, cycling, running, rollerblading, hiking, as well as greater social contact and the local culture through the activities taking place on the streets, in parks and squares:

Enouncement 5 - The municipal government seeks to create a city dedicated to its people.

In all 03 projects approached in this research it is possible to assume that they are dedicated to the residents of the city, aiming a to create a better city to live, to enjoy, to have a healthier life, to promote more contact with a local culture. Although the projects involve changes in habits, these involve three positive aspects for humans: (1) better health, (2) greater access to local culture and (3) greater social coexistence with less concern with urban violence.

Figure 5 - Integration and participation of communities in the districts

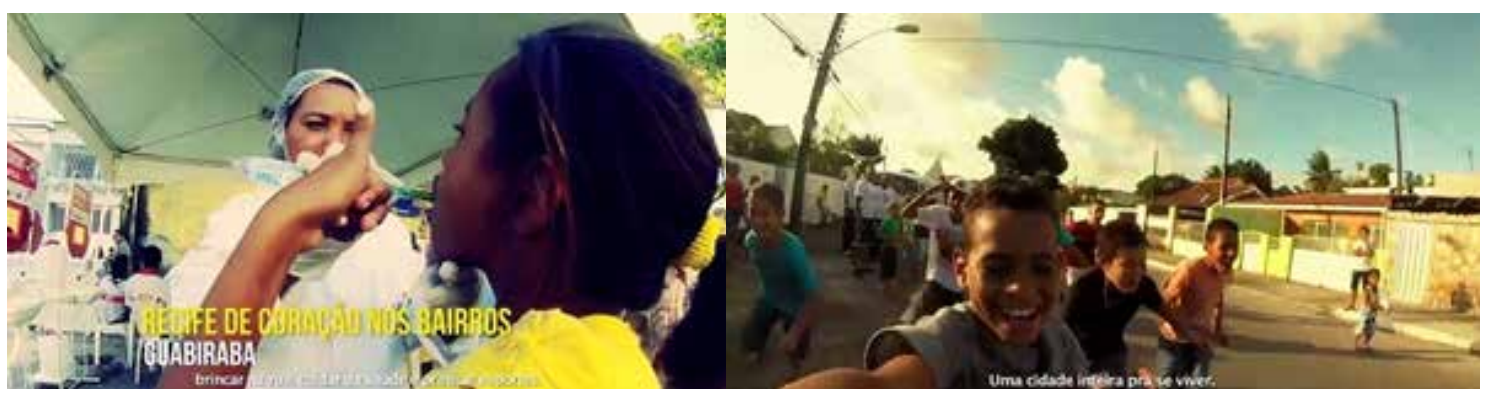

Source: PREFEITURA DO RECIFE, 2014. 
Enouncement $\mathbf{6}$ - The city government invests and enjoys the natural resources of the city particularly the banks of the river Capibaribe, in order also to enhance the quality of life of inhabitants, as well as provide new leisure and entertainment options.

This enouncement refers to the promotion of the use of the natural beauty of the city, towards to promote the population entertainment, providing a better quality of life, with respect to sports practices, recreation and good social coexistence. Being a city located between rivers, known as the Venice of Brazil, besides being the northeastern Brazilian coast, with temperatures ranging between $21^{\circ} \mathrm{C}$ and $33^{\circ} \mathrm{C}$ throughout the year, the city has a privileged nature with many trees typical of the rainforest and mangrove vegetation. In short, conditions that favor have practice finds the activities outlined above.

Enouncement 7 - Nowadays younger are the ones who most enjoy public spaces for social cohesion as well as for performing sports, leisure and cultural activities.

The "corpus" used in this research, almost entirely presented images showed that all these projects are enjoyed and structured to certain population profiles, namely younger citizens and young families. Thus, it's possible to affirm that the pictures deny words, since these projects are presented as a means of social inclusion. This apparently contradictory is capable of understanding the extent that analyzes and highlights the aspects of promotion, publicity and persuasion presents in public activities and policies.

Figure 6 - Local population involved in the activities provided by the local government

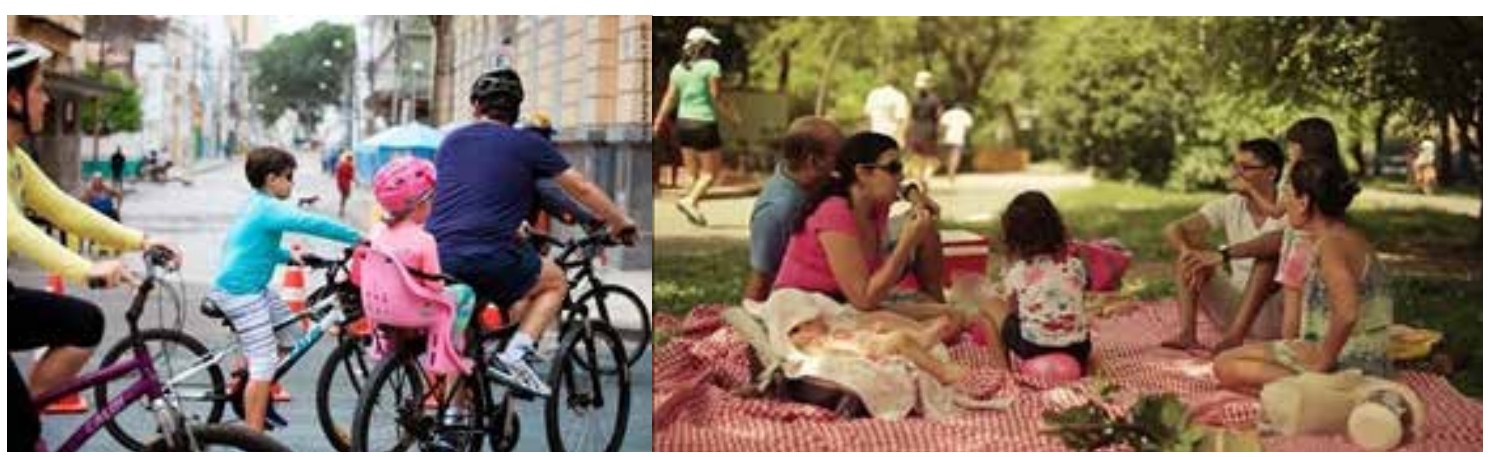

Source: PREFEITURA DO RECIFE, 2014.

Enouncement 8 - Assign the Capibaribe River central importance in the project, although there are no projects that looks after cleaning and conservation, only its promotion.

Although one of the major projects on the promotion of social harmony and sports practices refers to the River Capibaribe, there are no cleaning forecast and no conservation program to the river. The project refers to provide greater interaction of the population with this river, by creating green spaces, bike paths and bridges, the latter being exclusively built for pedestrians and cyclists. It should be noted that despite the inclusion or that highlighting the Capibaribe River, which cuts several important areas of the city, there is no projects exclusively for its cleanliness and conservation. 
Enouncement 9 - The prime areas of the city are those that particularly benefit from the Project.

The more structured neighborhoods or areas, with less violence and higher income levels were being erected along the River Capibaribe. Thus fostering a greater interaction and use of this urban space, directly benefits the residents living in these neighborhoods, who already have a privileged structure.

Figure 7 - Benefited from the project

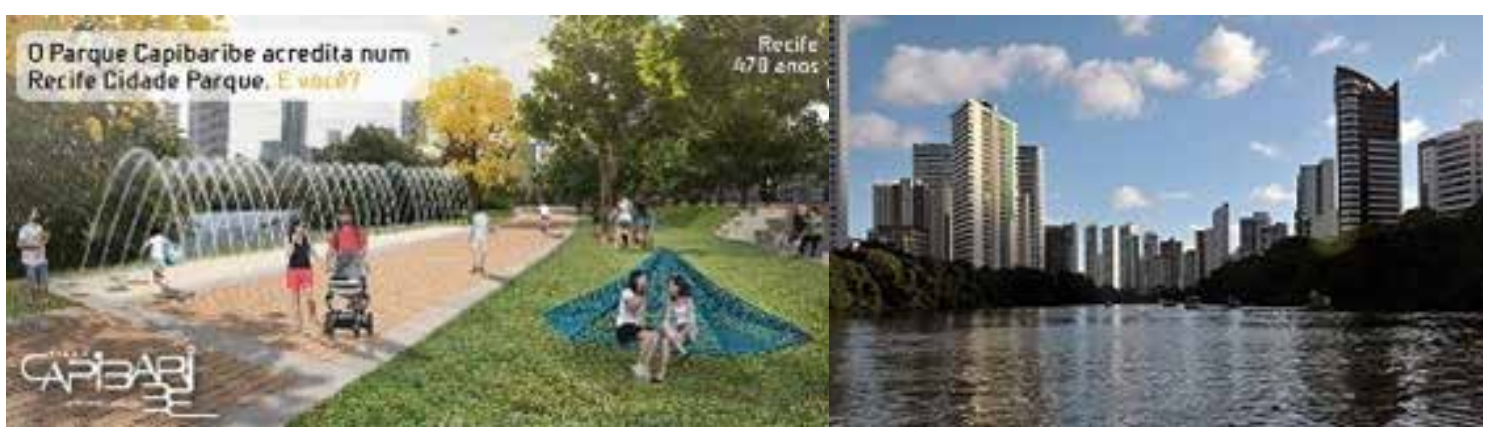

Source: COMUNIDADE PARQUE CAPIBARIBE, 2015.

The enunciative functions besides being carried out by enouncements, from the handling of these, are identified from a structure as a means of existence in an area of truth or knowledge. Thus, through the analysis of the discursive practices, as well as it occurred with the enouncements, it was generated and established eight (8) functions that their descriptions and actions will be displayed:

Figure 8 - Enouncements Functions

\begin{tabular}{|l|l|}
\hline \multicolumn{1}{|c|}{ Name } & \multicolumn{1}{c|}{ Resulting Action } \\
\hline Function 1 - To Legitimate & Legitimate actions and projects of local Government \\
\hline Function 2 - To Justify & Justify government investments and legislations changes \\
\hline Function 3 - To Persuade & Persuade the population to support the project \\
\hline Function 4 - To Provide & Providing entertainment and recreation \\
\hline Function 5- To Create & Create conventions and social habits \\
\hline Function 6 - To Experience & Experiencing new habits \\
\hline Function 7 - To Embed & Embed local cultural aspects to projects and new habits \\
\hline Function 8 - To Promote & $\begin{array}{l}\text { Promote harmonious coexistence among people, nature } \\
\text { and the city in which they live. }\end{array}$ \\
\hline
\end{tabular}

Source: Authors, 2019.

Function 1 - To Legitimate

Legitimize the coordinated actions of local government with the aim of receiving support for the decisions taken, the projects undertaken and the need to acquire new habits. 


\section{Function 2 - To Justify}

The process to justify the projects, actions, investments and regulatory changes is an integral part of the function of legitimizing. In addition, the efforts and resources to foster new activities, to change habits to better people's quality of life and a more intense and symbiotic relationship with their city, however they seem obvious benefits offered, the justification these investments in detriment to other appears as almost natural function of some statements.

\section{Function 3 - To Persuade}

Performs the function of aligning government interests, discursive agent, with the population. This function acts to the interests of maintaining order, peace and quality of life in a city closest to the population, remain present in the minds and concepts of the population, despite the existence of this concrete reality.

\section{Function 4 - To Provide}

Provide the population with more entertainment, promotion of local culture, sport and leisure activities, as well as a healthy social life.

\section{Function 5 - To Create}

Due to the absence, so far, in coordination and customary practices used throughout labor, local government seeks to create, encourage cultural habits, sports, leisure and living in areas linked to projects.

\section{Function 6 - To Experience}

The emanated speech from the "corpus" of this research points to various forms of virtual experiences of government projects. These experiences occur in the form of real images, testimonials, future virtual images and virtual realities future.

\section{Function 7 - To Embed}

Insert aspects and practices of the local culture in these entertainment projects, leisure, living together. This insertion on the one hand promotes, maintains and discloses the local culture, on the other hand favors the creation, promotion and the experience of new habits.

\section{Function 8 - To Promote}

Promote balanced and symbiotic relationships between people, nature and urban space where they play their social activities.

After the presentation and description of the actions of the functions, the rules of formation of speech are unveiled. The discursive rules are apprehended through the historical and social context, not linguistic resources, analytical concepts and, therefore, is the establishment of Foucault's true. The rules are structured from the determination of its objects, the result of discursive practice, concepts, system, which corresponds to the manner and form of discursive practice, and strategies, which in some ways are ways, assumptions. The rules are defined and formed within each discursive structure, and contains the above elements (FOUCAULT, 2007), as the figures 9 and 10: 
Figure 9 - Rules of Usage and its constituent elements

\begin{tabular}{|c|c|c|c|c|}
\hline \multirow{2}{*}{ USAGE RULES } & \multicolumn{4}{|c|}{ FACTORS AND CRITERIA } \\
\hline & OBJECTS & CONCEPTS & ARRANGEMENTS & STRATÉGIES \\
\hline $\begin{array}{c}\text { Use of } \\
\text { Biopolitcs }\end{array}$ & $\begin{array}{l}\text { Government } \\
\text { Policy }\end{array}$ & $\begin{array}{l}\text { Coordination, } \\
\text { control, fostering } \\
\text { the creation of } \\
\text { new habits and } \\
\text { feeling of safety, } \\
\text { guidance, and } \\
\text { surveillance }\end{array}$ & $\begin{array}{l}\text { F o r m a t i v e, } \\
\text { Punitive, rules, } \\
\text { and standardized }\end{array}$ & $\begin{array}{l}\text { To demonstrate the } \\
\text { improvement of } \\
\text { quality of life and new } \\
\text { opportunities for leisure } \\
\text { and social life offered } \\
\text { structured by the } \\
\text { government in the city } \\
\text { of Recife, improving and } \\
\text { developing their natural } \\
\text { and historical resources }\end{array}$ \\
\hline $\begin{array}{l}\text { Sustainability, } \\
\text { quality of life } \\
\text { and social } \\
\text { change }\end{array}$ & $\begin{array}{l}\text { Government } \\
\text { Policy, change } \\
\text { of social } \\
\text { habits }\end{array}$ & $\begin{array}{l}\text { Motivation, } \\
\text { integration, } \\
\text { involvement, } \\
\text { social cohesion } \\
\text { convincement, } \\
\text { fostering the } \\
\text { creation of new } \\
\text { habits and feel- } \\
\text { ing of belonging } \\
\text { and, guidance. }\end{array}$ & $\begin{array}{l}\text { For m a t i v e, } \\
\text { I n t e g r a t i v e } \\
\text { behavior and } \\
\text { social cohesion } \\
\text { and creative }\end{array}$ & $\begin{array}{l}\text { Demonstrate the } \\
\text { improvement in } \\
\text { quality of life and new } \\
\text { opportunities for leisure } \\
\text { and for a balanced social } \\
\text { life, where the feeling } \\
\text { of belonging and the } \\
\text { social and environmental } \\
\text { development of the city } \\
\text { is built and used by all. }\end{array}$ \\
\hline
\end{tabular}

Source: Authors, 2019.

From the statements interacting with the functions it has been the use of rules for the discursive formation. In this research appeared two discursive rules which are to (1) the use of bio-politics and (2) sustainability, quality of life and social change.

Figure 10 - Usage Rules and Applications

\begin{tabular}{|c|c|}
\hline USAGE RULE & DESCRIPTION \\
\hline $\begin{array}{c}\text { Use of Bio- } \\
\text { politics }\end{array}$ & $\begin{array}{c}\text { Influence the change of behavior of citizens from Recife } \\
\text { through opinion formation, persuasion and control. }\end{array}$ \\
\hline $\begin{array}{c}\text { Sustainability, } \\
\text { quality of life and } \\
\text { social change }\end{array}$ & $\begin{array}{c}\text { Influence to create new lifestyle habits that promote } \\
\text { sustainability, a more equitable and fair relationship with the } \\
\text { environment and the people who live and coexist in the city. }\end{array}$ \\
\hline
\end{tabular}

Source: Authors, 2019.

The first one, more general and more macro is intended to influence the formation of opinion and the knowledge of the residents of the city of Recife, about this practice closer to your city when it comes to quality of life, access to culture and social interaction safely. It is noteworthy that the specific purpose of this discursive rule is not to improve the infrastructure to ensure access to all the benefits by all citizens. Indeed, these goals are aligned more with the use of devices and bio-politics mechanisms, to be discussed later, to ensure that the perception of investments, decisions, changes in government regulations and taxes, is positive. It is noteworthy that bio-po- 
litics is the government policy, carried out through the concepts coordination, control, guidance, supervision, encouraging the creation of new habits and sense of security, the information, protective, proactive and standardized manner, through strategy to highlight the increasing quality in both quality of life in the city, as the interaction between government and citizens. The latter considerations concerning the use of rule of bio-politics actually seek to explain all the rule of the working mechanism, that is, how it is applied, for what purpose and what it says about the fact (FOUCAULT, 1999, 2008a).

The second one is more specific and directs people to seek experience the city in order to improve their quality of life, sustainable purchasing habits, ie, aims to promote social change, even if it is restricted to specific locations and audiences. The way individuals enjoy the resources is directly related to the commitment they have with the performance of its activities. In order to modify the resource use practices it is necessary to promote the renegotiation of intensive habits resources, eradicating them and boosting the emergence of sustainable habits. Thus, the process of change in daily practices is fundamentally discursive, inviting people to reflect and to question about their actions and their lifestyles. Through this questioning is possible to negotiate the meanings attributed to the way resources are used and discuss ways for people to become less dependent on infrastructure and unsustainable lifestyles, improving their quality of life (CHAPPELLS; MEDD; SHOVE, 2011).

In this sense, the focus of understanding of sustainability is no longer the individual and becomes practical, since the engagement of people takes place at the level of practices disseminated in time and space in the sociocultural context. While this approach move the human being the center of the debate by putting the practices with which is central factor, are the practitioners that "simultaneously reproduce the practices in which they are engaged and the elements that these practices are made" (SHOVE; PANTZAR; WATSON, 2012, p. 22). Thus, his life begins to be understood as a succession of practices with which people engage in because of the speeches that give more or less emphasis on different aspects in certain temporal and locational spaces.

\section{FINAL REMARKS}

Finally, after using the archaeological analysis of discourse it is possible to structure the entire process carried out with the relevant steps and interrelations, in order to facilitate the understanding of using the method of the framework and the results achieved, as shown below: 
Figure 11 - Summary Map Analysis

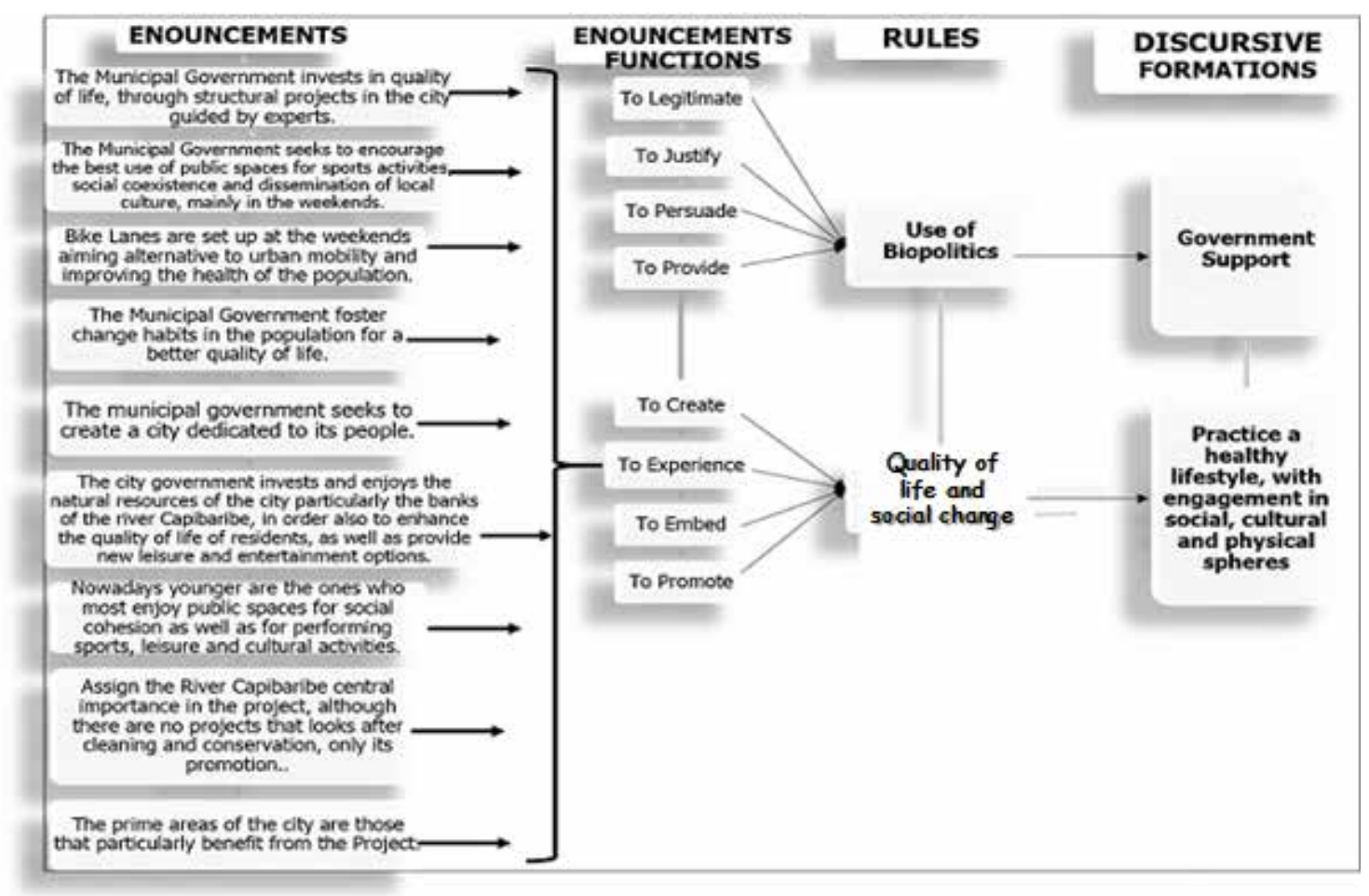

Source: Authors, 2019.

According to the figure presented above, we conclude that there were two discursive formations, namely: (1) the protection of the Government (State) and (2) healthy lifestyles practices, with the inclusion of social, cultural and physical. Obviously, according to the previously explained and the table above, this discursive formation is founded on the pillars of biopolitics and sustainability, quality of life and social change.

Regarding the discursive formation "state protection", it is important to highlight something that is part of the theory to be presented in the next section, however, aids in understanding and in understanding the structure of it. According to Foucault (2008b, p. 61) the current concept of the State Protection is linked with the notion of to feel the security:

... security without prohibit or prescribe, but obviously giving some prohibition instruments and prescription, security is essentially function responding to a reality so that this response defeat this reality to which she replies, cancels, or limit, or brake, or adjust. This regulation on the element of reality is that it is, I believe, crucial in security devices.

The state protection is therefore through the security devices that seek to strengthen the positive elements of society, such as peace, social life, the free movement of people and goods, the constructions carried out properly and reduce the possible elements negative - disease, disasters, accidents and other (FOUCAULT, 2008b). Thus it is possible to conclude that, under the biopolitics, there is a quest for normalcy in the state, which would correspond to an asymmetry of state power over its population, however, ensuring the perception and the balance of the positive elements of society. That said, the discursive formation of state protection, found in this study approaches to the notion of security and normality presented by Foucault. 
Regarding the discursive formation "healthy lifestyles practices" it is evident that such training is theoretical basis of the study who view sustainability as a social practice. In the face of environmental problems experienced by today's society and prospects of these are exacerbated in the near future, sustainability has become an issue widely debated. In this context, education is being understood as a key factor in the discussion about the direction of society. To Gadotti (2000) knowledge will be part of any prospect envisioned for the future. In a context known as the 'information age', in which technological advances are undeniable all spaces have become educational. But the favorable learning space by itself is not enough, it is necessary that the information is accessible, and that social participation is intensified.

There is a general understanding of the challenge of climate change, which shows that the way Western societies live and many of their consumption patterns are unsustainable (SHOVE, 2012). There are various interpretations about how governments should act to influence people's behavior and how cultural factors work in this process. The existence of multiple approaches on the theme should contribute to the conceptual and practical advances in the area. However, speeches about "change are situated inside a bubble in the intellectual space, protected and isolated from the conceptual developments elsewhere in the social sciences" (SHOVE, 2012, p. 2). Thus, the author believes it is vital to have a social change, arguing that to make popular sustainability is necessary to articulate the political implications so that it becomes a social practice (RECKWITZ, 2002; SCHATZKI; CETINA; SAVIGNY, 2001) instead of setting himself only as isolated individual actions and attitudes.

Based on the analyzed data and theories that support the vision adopted in this study can be seen that the speech "Recife city of the people" has the intention to influence people's opinions about public spaces and mobility in Recife.

The experiences in big cities has become increasingly restricted to private, both because of the sense of existing insecurity, the need for increasingly vehement consuming. Enabling laser options and entertainment in public spaces enables improvements in quality of life, promoting social interactions that lead to social change. However, analysis of the statements shows that the projects are restricted to certain public spaces, which favor older and affluent neighborhoods. Another factor to be seen is that the audience reached is also specific and restrictive, including mainly young people.

Moreover, in a context in which the mobility theme has been consolidating as one of the serious problems of our time, both because of existing traffic jams in big cities, as the issue of harmful gases to the environment, direct the public to realize improvements in Mobility adds image value. However, the proposal viewed in the videos studied expressed that the actions do not lead to an effective mobility, since they are confined to weekends and holidays, not leading to permanent solutions.

\section{REFERENCES}

BERGER, P. L.; LUCKMANN, T. The social construction of reality. New York: Doubleday, 1967.

CHAPPELLS, H.; MEDD, W.; SHOVE, E. Disruption and change: drought and the inconspicuous dynamics of garden lives. Social and Cultural Geography, 12:7, p. 701-715, 2011.

COMUNIDADE PARQUE CAPIBARIBE. Página do Facebook. Disponível em: https://www.facebook.com/ parquecapibaribe/photos_stream. Acesso em: 1으 maio 2015. 
CRESWELL, J. W. Projeto de Pesquisa: métodos qualitativo, quantitativo e misto. 3. ed. Porto Alegre: Artmed, 2010.

DENZIN, N. K.; LINCOLN, Y. S. Introdução: a disciplina e a prática da pesquisa qualitativa. In: DENZIN, N. K.; LINCOLN, Y. S. (org.). O planejamento da pesquisa qualitativa: teorias e abordagens. 2. ed. Porto Alegre: Artmed, 2006. p. 15-41. Cap. 1.

FAIRCLOUGH, N. The dialectics of discourse. Textus, XIV, 2, p. 231-242, 2001.

FOUCAULT, M. Vigiar e punir: nascimento da prisão. 20. ed. Petrópolis: Vozes, 1999.

FOUCAULT, M. A arqueologia do saber. 7. ed. Rio de Janeiro: Forense Universitária, 2007.

FOUCAULT, M. Nascimento da biopolítica: curso dado no Collège de France (1977-1978). São Paulo: Martins Fontes, 2008a.

FOUCAULT, M. Segurança, território, população. Curso dado no Collège de France (1977-1978). São Paulo: Martins Fontes, 2008b.

GADOTTI, M. Perspectivas atuais da educação. São Paulo em Perspectiva, São Paulo, v. 14, n. 2, apr./june 2000.

GOMES, Roger Marcelo Martins. A arqueologia do saber: uma proposta metodológica para a análise do discurso em História. Interfaces Científicas-Humanas e Sociais, v. 6, n. 3, p. 19-26, 2018.

GRAMSCI, A. Selections from the Prison Notebooks. London: Lawrence \& Wishart, 1971.

LINCOLN, Y. S.; GUBA, E. G. Controvérsias paradigmáticas, contradições e confluências emergentes. In: DENZIN, N. K.; LINCOLN, Y. S (org.). O planejamento da pesquisa qualitativa: teorias e abordagens. 2. ed. Porto Alegre: Artmed, 2006. p. 169-192. Cap. 6.

MACHADO, Roberto. Ciência e saber: a tragetória da arqueologia de Michel Foucault. São Paulo: Editora Graal. 1981.

MCLUHAN, H. M. Os meios de comunicação como extensões do homem. São Paulo: Cultrix, 2001.

MERRIAM, S. B. Qualitative research and case study applications in education. San Francisco: Jossey-Bass, 1998.

MERRIAM, S. B. Qualitative research: a guide to design and implementation. San Francisco: Jossey-Bass, 2009.

PAIVA, F. G., JR.; MELLO, S. C. B. Pesquisa qualitativa nos estudos organizacionais: contribuições fenomenológicas de Alfred Schütz. Organizações em Contexto, ano 4, n. 8, dez. 2008.

PREFEITURA DO RECIFE. Canal do Youtube (2014). Dísponível em: https://www.youtube.com/user/prefrecife/videos. Acesso em: 11 mar. 2019.

RECKWITZ, A. Toward a theory of social practices: a development in culturalist theorizing. European Journal of Social Theory, v. 5, n. 2, p. 243-263, 2002.

SCHATZKI, T. R.; CETINA, K. K.; SAVIGNY, E. V. The practice turn in contemporary theory. London: Routledge, 2001.

SHOVE, E. Putting practice into policy: reconfiguring questions of consumption and climate change. Journal of the Academy of Social Sciences, 2012.

SHOVE, E.; PANTZAR, M.; WATSON, M. The Dynamics of Social Practice: Everyday life and how it changes. London: Sage, 2012.

SPINK, M. J. P.; FREZZA, R. M. Práticas discursivas e produção de sentido. In: SPINK, M. J. (org.). Práticas discursivas e produção de sentidos no cotidiano. Rio de Janeiro: Edição Virtual, 2013.

SPINK, M. J. P.; MEDRADO, B. Produção de sentido no cotidiano. In: SPINK, M. J. (org.). Práticas discursivas e produção de sentidos no cotidiano. Rio de Janeiro: Edição Virtual, 2013. 